Liberalism, Democracy and the Turkish Centre-Right: The Identity Crisis of the True Path Party

Author(s): Ümit Cizre Sakallioğlu

Source: Middle Eastern Studies, Vol. 32, No. 2 (Apr., 1996), pp. 142-161

Published by: Taylor \& Francis, Ltd.

Stable URL: https://www.jstor.org/stable/4283797

Accessed: 31-01-2019 17:02 UTC

JSTOR is a not-for-profit service that helps scholars, researchers, and students discover, use, and build upon a wide range of content in a trusted digital archive. We use information technology and tools to increase productivity and facilitate new forms of scholarship. For more information about JSTOR, please contact support@jstor.org.

Your use of the JSTOR archive indicates your acceptance of the Terms \& Conditions of Use, available at https://about.jstor.org/terms

Taylor \& Francis, Ltd. is collaborating with JSTOR to digitize, preserve and extend access to Middle Eastern Studies 


\title{
Liberalism, Democracy and the Turkish Centre-Right: The Identity Crisis of the True Path Party
}

\author{
ÜMIT CIZRE SAKALLIOĞLU
}

In recent years there has been a sharp deflation of the left in political societies throughout the world. Accompanying this global trend has been the general acceptance of the primary tenets of neo-liberalism,' namely: political centrism; pragmatism; moderation; depoliticization; social and economic reforms that roll back the 'social' state; and the establishment of market capitalism. Neoliberal ideas provided the impetus for the quality of political democracy and economic liberalization in post-1980 Turkey. This context allowed the centre-right political parties ${ }^{2}$ to adopt the agenda of neo-liberalism and to obtain historical electoral results on behalf of the Turkish Right. The new postmilitary era relied on the 'taming of the right' ${ }^{3}$ into the new rationale of the market-oriented model. In theory, this required a fundamental alteration in representative politics and in political parties traditionally dependent on stateadministered patronage. It was also to involve a laborious transformation process in the political identity of centre-right parties, reorganizing political representation based on 'ideas' rather than on state largesse.

This article will examine the identity struggle of the True Path Party (TPP), the senior party of the present coalition government as well as the current dominant party of both the Turkish Right and the electoral arena in general, since its birth in 1983. The implications of this analysis go beyond a dramatic account of the TPP trying to recapture the lost leadership of the Turkish Right which once belonged to its predecessor, the Justice Party (JP), which had been a key party during the three military intervention periods of 1960 (the JP was formed after the military relinquished direct rule in 1961), 1971 and 1980. In an era of international and domestic consensus on neo-liberalism, examining the TPP's identity struggle in the post- 1980 period creates a better understanding of three important current problems in Turkey's experiment with democracy.

First of all, this struggle highlights the dynamics and contradictions which the shift to economic liberalism has produced in the character of the Turkish centre-right. Given the historical strength of Turkish centre-right parties as independent actors, the TPP's commitment to liberalization has been impeded 
by a legacy of ideological fuzziness, the uneasy existence of state-dependent features with more liberal sounding elements within a leader-based structure. Secondly, the identity crisis of the TPP was a product of the enduring effects of a 'transition' into democracy by authoritarian means. ${ }^{4}$ The military regime (1980-1983) and the ruling party of the 1980s, the Motherland Party (MP) (1983-1991), altered the social bases of politics and the institutional framework for competition. ${ }^{5}$ Thirdly, the post- 1983 quest by the TPP for a new political identity reflects the resurgence of neo-conservatism ${ }^{6}$ in terms of its particular version of 'politics of anti-politics' on a global scale. This is especially true since Tansu Çiller took over the party's leadership in 1993. These three variables also contribute to an understanding of why the formation of the political profile of the TPP has reached a crisis state.

The post-coup military leaders recreated Turkey's political economy by having greater autonomy from social forces than was previously present. The reason for this autonomy was the profound state crisis on the eve of the 12 September 1980 military intervention. The foundation for a shift to an alternative economic model based on a free market economy was to be laid by the creation of a socially disciplined and politically depoliticized society through legal-constitutional instruments. A unique synthesis was made as economic liberalism was promoted through a conservative-authoritarian political agenda as opposed to political liberalism. The adoption of this formula entailed a new phase of entry into the global economy and was facilitated in part by the structural disintegration of the Republican-old economic development model of etatism.

The process of restructuring the political system unleashed two major dynamics which impeded the TPP from mustering a political force similar to its predecessor, the JP, which had been the leading party on the right before 1980. The first was the consolidation of the right within the MP. Ironically, the second factor was the fragmentation of the right beginning with the conspicuous emergence of the TPP in the local elections of 1989.

To a very large extent, the rise of the MP as the dominant party of the Turkish Right was given impulse by the vetoes and bans ${ }^{7}$ employed by the military before the first post-coup elections in 1983, which took place in an authoritarian context. That is why it is quite possible to form a political causality between the denial of the TPP's baptism into the new 'democratic' order and the consolidation of the right-wing tendencies within the MP. In the first half of the 1980s the TPP's inherited support from its predecessor party thinned, ${ }^{8}$ its appeal declined and its isolation grew. This was due in a real sense to the political engineering of the ruling military and its mostly willing ally, the MP, to prevent the TPP from relaunching itself and effectively manipulating and mobilizing its traditional clientele. What proved vital for the succession struggle on the right and left was the military's holding all pre-1980 
political parties responsible for the near civil war situation which had initially prompted the military take-over. In a political climate where the ruling elite 'exploited the issue of pre-1980 anarchy',' the TPP was faced with the task of relegitimizing itself as the successor of an old party and was consequently forced into a politics of subsistence until the beginning of the 1990s.

The defensive discourse of the party was, then, a combined product of structural conditions of the era and the ideological bias of the ruling elite. After the initial consolidation of the Turkish Right in the MP, the ruling party built a mass base of support among large urban, middle and lower classes, ${ }^{10}$ becoming in the process the fastest growing political party in Turkish history. Both the MP and the military government which preceded it were committed to rolling back the 'etatist' and 'populist' policies of the Turkish state. A main difference between the two administrations was, however, the historic assault of the MP against bureaucracy, articulated with a democratic political project and a centrist-pragmatic discourse. This tendency had been evident among the electorate since the late $1970 \mathrm{~s}^{11}$ and its implementation was central to the consolidation of the role of the party.

Despite its dubiously liberal character, ${ }^{12}$ the MP stole a march on the TPP by its supreme success in making economic liberalism a political agenda for mobilizing Turkey's traditionally conservative constituencies. The MP challenged the traditional forces within the right by its ideological commitment to a free-market economy incorporated into a democratic and popularized discourse. However, starting in 1987 a general disenchantment with the party became more and more evident. This was mainly due to the social ravages caused by the free-market orthodoxy among the middle classes, the bulk of the MP's social base. There was also a question of credibility, as the MP governments continued to expand the state's role in the economy despite hollow rhetoric to the contrary.

The 1989 local elections marked a historic watershed in the development of the TPP's political profile as it confirmed the trend toward fragmentation and heterogeneity within the Turkish Right ${ }^{13}$ that had begun two years earlier. The votes the TPP received in the 1989 election were 6 per cent higher than its 1987 share, a modest sign of increased electoral appeal. However, this also signalled their failure to integrate with the popular potential of neo-liberalism which had popularized political centrism based on moderation, compromise, pragmatism and free-market reform. There was no doubt that economic reform in the 1980s, which was perceived as part of the global process, had gained primacy over political reform. Because of the crisis that global national capitalisms entered, the old Republic inward-oriented development and the forms of bureaucratic domination that had sustained it became outdated. ${ }^{14}$ Social and political forces like Islam and Kurdish movements began to push 
for a new social consensus based on cultural and political differences. ${ }^{15}$ Stateshrinking free-market capitalism became a regular discourse and almost a collective consciousness of all political contenders on the right.

To scramble for a place under the centre-right's sun, the TPP was now faced with the challenge of constructing and deepening an identity for itself, as distinct from its original mission of continuing the political legacy of its predecessor, the JP. The new identity would revolve around abandoning not only the defensive and aggrieved posture the party had adopted since 1980, but also the JP's ideological legacy. It had to articulate neo-liberalism as the new political logic built around an economistic discourse and centricist locus. It is at this point that the crisis potential of the generic conditions of the TPP surfaced.

One chief protagonist who realized the limiting effect of the political heritage of the party in all three areas was Hüsamettin Cindoruk, elected as their third leader in the first party congress on 14 May 1985. As the party's chief architect of national political strategy until 1987, when the political ban on its natural leader, Süleyman Demirel, was lifted, Cindoruk was quick to acknowledge a '. . . developed and changed constituency since 1980 '. ${ }^{16}$ Although his daring and reformist posture, called 'contemporary new line', caused some estrangement between hard core Demirel supporters and those of his own, he basically reduced the problem of dwindled electoral appeal of the party to a question of it being merely leader-based (Demirel implied). He suggested a renewal of both the TPP leadership and its cadres: 'It is no use following a political line dependent on one person ... we need a more qualified and intellectual party management and cadres. ${ }^{17}$ Since an organizational renewal could not be considered independent of a change in discourse and ideology, which essentially involves an identity-forming process, inclusion of new faces into policy making positions in the third extraordinary congress of 23 November 1990 did not go beyond window-dressing. ${ }^{18}$

One typical feature of all Turkish political parties has been the unquestionable authority of the leader unconstrained by party structures. The locus of power and initiative within the parties has always been in leadership characterized by personalistic decision-making and a monolithic internal structure. No political faction or actor can act autonomously from the will and actions of the leader. It is, in short, the charisma of the leader sustained by a lack of internal democracy, rather than the charisma of an ideology, that acts as a source of support. The problem is obviously related to the existence of a political culture that prioritizes state-building over consolidation of democracy. Since political parties are the strongest agents for converting the political culture, there is reason to believe that Cindoruk's appeal for more internal democracy and a changed system of leadership recruitment would be a necessary, if not sufficient, step in the reformulation of the identity of the TPP. In other words, 
the autonomy of the internal set-up of a political party from its social base works together with the support base in shaping the identity of a party.

At the heart of the TPP's difficulty to come to terms with the dominant paradigm of post-1980 neo-liberalism was its pro-state conservative ideological past. Its historical antecedents, the Democratic Party (DP) and JP, were never unambiguously 'liberal'. As parties of the 'periphery', they depended on the cleavage between the central bureaucratic elite and the peripheral masses within the structure of existing relations of domination. The appeal of both parties 'was not ideological but was (is) rooted in the social structure of Turkey'. ${ }^{19}$ In other words, the key explanation for the lack of an ideological commitment by this political tradition to economic and political liberalism lies, from the very beginning, in the evolution of the specific nature of its social base. Liberalism for this core constituency of small-holder peasants, rising commercial and urban groups represented a dilemma on two fronts. On one hand, the base was organically linked to the state by etatist subsidies and protection, in the hopes that they would be able to gain wealth through state largesse. On the other hand, to the extent that the Cold War anti-communist ideology of the state reinforced the political and social conservatism of the periphery, the rising Turkish bourgeoisie was in demand of 'relative freedom' from the strait jacket of bureaucratic controls. They were not, therefore, interested in political liberalism ideally understood as a limited state in classical liberal tradition.

Demirel's refusal, as late as 1965 , to embrace liberalism should be taken as a sign of the comfort felt among the Turkish Right in having a power base whose interests did not coincide with doctrinaire liberalism. 'We are against all "isms" including liberalism and capitalism ... We are not for any diehard ideology or system. We establish our economic view in accordance with the conditions of the day. ${ }^{20}$ Originating in conditions surrounding its birth, pragmatism, since it substituted for clarity in thought and action, eventually became the most important ideological fault line for the centre-right tradition in Turkey. It almost became a euphemism for inconsistent and conflicting policy stands on important political issues.

The DP-JP tradition, therefore, was rooted in a contradiction: it articulated the popular resentment against the state into a basically state-oriented discourse. The growing antagonism between state and society brought about by the difficulties of distributing populist benefits to the masses after the Second World War ${ }^{21}$ proved instrumental in this strategy of double discourse. Although the traditional discourse of the Turkish Right was always anticommunist, anti-central planning and encouraged the development of the private sector, it never intended to lose its grip on the penetrative power of the state through populist controls and bureaucratism. Because it relied on a conservative popular base, in a sense it reproduced a socially more conserva- 
tive populism than the one upheld by westernizing state elites. Ironically enough, however, in doing this it enabled the modernizing elements of the official state ideology to make inroads into a wider constituency. ${ }^{22}$

It would be unfair to interpret the coincidence of purpose between the state and the Turkish Right as one of co-optation. On the contrary, the history of military interventions bears witness to the tense acceptance of the Turkish state elite of the peripheral right to shape political outcomes through the electoral process. All in all, the etatist attitude and populist policies of the Turkish Right highlights the ability of the Turkish state to incorporate peripheral tendencies without undermining their political and cultural peripheralism.

Therefore, the historically derived schizophrenic nature of the DP-JP tradition is reflected in its lack of ideological coherence and clarity in policy platforms which were concretized in its pragmatism. What provided an appearance of unity and coherence was loyalty to its leader, rather than to any set of ideas or policies. This weakness proved to be lethal to the identity formation process of the TPP after 1980 . The changed voter profile further aggravated the problem. The voters now indexed their loyalty to those in power to their performance. They also supported those who showed great potential to adapt to the idea, if not the reality, of anti-etatist and centricist values of neoliberalism and to the structural disintegration of a state-oriented model of capitalist development.

Another confounding problem which made it difficult for the TPP to embrace neo-liberalism in no uncertain terms, thus shedding its etatist and populist outlook, was the 'conservatizing' effect of economic liberalization felt in many non-western countries, including Turkey. The societal disorganization caused by the economic reforms of the MP governments produced 'a large mass of potential right-wing voters, socially uprooted and easily available to the appeals of the new breed of ... conservatives' ${ }^{23}$ Thus, to protect the disintegrating sectors of lower middle classes and the peasantry against the corrosive effects of market liberalism, the party had to emphasize conservative-populist elements in its discourses.

Faced with the inability to transcend the vagueness of its ideology which was conditioned by its traditional double discourse, the TPP resorted to the proven method of drawing its own political profile. The predecessor parties, constrained by their lack of ideological clarity, had not defined themselves by what they stood for but by their contrast to the Republican People's Party, their state-oriented main political rival. ${ }^{24}$ Defining its ideological orientation in a 'minimal' way and in relation to 'the other' has, since then, remained the most important structural feature of the DP-JP-TPP's political tradition. The construction of the TPP's identity also became dependent on negating some unsavory aspects of the neo-liberal discourse of the MP, rather than on crystallizing its own ideological commitments. It is not surprising, therefore, that 
until Tansu Çiller's election as the new leader in 1993, one main constituent of the political identity of the TPP became an attack on the softest flank of the MP, the area of social policy. The TPP's historic suspicion of liberalism was conveniently used to exploit the dislocating social effects of a free-market economy. The old state-friendly posture was revived under the pretense of 'combining societalism and liberalism', ${ }^{25}$ or for 'a more egalitarian distribution of economic resources among the individuals comprising the society' ${ }^{26}$ so that 'Public Economic Enterprises will be used to implement an economic rationale with social content' ${ }^{27}$ It would be correct to say that this discourse was directed towards the suffering core supporters, the lower middle classes, the small and medium-sized businesses and the peasantry.

The social welfare discourse of the party reached its culminating point with the Election Manifesto of 1991, which combined a commitment to a true free market economy with the promise of an extensive list of social welfare provisions. ${ }^{28}$ Realizing the incompatibility between these divergent goals, Demirel was quick to point a way out of this dilemma: the growth inducing potential of the free-market economy would pay the costs of the social services. ${ }^{29}$ However, despite increasing social polarization and falling living standards, the coalition government of the TPP and the Social Democratic Populist Party (SDPP) (1991- ) failed to implement any significant changes in the social policy area. With Çiller's state-shrinking rhetoric, a complete reversal came, social improvement would be effected by the benefits accruing from tax reform and privatization. ${ }^{30}$

Perhaps the most crucial item that the party grabbed as a life-line to define its new identity vis-à-vis the MP, was its rhetoric on 'democratization' and 'civilianization'. The TPP once more made a frontal assault on where the MP failed most, establishing political democracy. It is important to note that while the social welfarism of the party was designed to address the needs of its core constituencies, democratization discourse aimed at deepening and popularizing the identity of the party outside those strata. Contrary to the statist orientation of the welfarist approach, democratization rhetoric relied on generating and expanding support among the non-core elements, the urbanites, who had already been converted into strong believers of economic and political liberalism through the process of opening up to the outside world. Thus, it could be claimed that in trying to uphold two seemingly contradictory discourses simultaneously the party's identity was shaped once more by the familiar strategy of eclecticism. The course that this strategy took well verifies the difficulty of sustaining this combination. This line of activity will now be analyzed in two distinct periods, one bearing Demirel's and the other Çiller's imprints.

Democratization as a precondition for the TPP's growth, and as one of the most vital elements shaping its identity, emerged in its formative years. Even 
under the three leaders preceding Demirel it was nevertheless carried on with the latter's full endorsement, as Demirel was the unchallenged strategist behind the scenes at that time. The pre-Demirel discourse was characterized by a three-tiered struggle: the first revolved around the concept of 'national will', the second around the campaign to remove the 'undemocratic' items in the Constitution and the third was based on civilianization of the regime.

For the Turkish centre-right, 'national will' ${ }^{31}$ has historically been the near mythical concept that provides political legitimacy centreed on popular sovereignty. Being based on the majoritarian logic of electoral politics, it has excessively focused on legitimation through a return to the origins of power. Unlike western liberal tradition, it has not emphasized the sources of the democratic legitimation of the limited state through respect for the rule of law, civil society and constitutionality. ${ }^{32}$ The Turkish centre-right has, therefore, typically occupied itself with questions of electoral mathematics, number of seats in the assembly, percentage of votes received and coalition arithmetic. Sacrificed in this preoccupation has been an interest in putting the rights of the individuals vis-à-vis the state at the centre stage of its political agenda. In the formative years of the 1980s, especially when the party was banned from participating in the 1983 election, this concept was instrumentally used to claim that the MP governments were in fact illegitimate. ${ }^{33}$

The second theme of democratization $\grave{a}$ la Demirel was centred on the removal of two provisions of the Constitution. One of these impeded the political rights and freedoms of the former leaders and top cadres of the old political parties (Provisional Article No.4) while the other exempted the decisions of the National Security Council, the ruling military body between 1980-1983, from judicial review (Provisional Article No.15). More important, however, was the third leg of the discourse on democratization, which made a strong assault on the continuing political role of the military, from within its post- 1980 constitutionally secure position, ${ }^{34}$ and demanded the establishment of the principle of civilian control over them. The MP was portrayed by the TPP as '... the tail of the coup" ${ }^{35}$ and as 'using ... the political influence of the military for furthering its own political fortunes' ${ }^{36}$ This anti-militarist stance of the TPP was directed at building an identity through the failure of the MP to end the key political role of the military as a constraint on civilian governments. $^{37}$

There were three major reasons why the whole Demirel-led anti-militarist discourse of the TPP did not have a broad popular democratic appeal. To begin with, the restrictive provisions of the 1982 Constitution on the civil society were essentially in the same direction as the pre-1980 rhetoric of the then ruling party, the JP, on 'consolidation of the democratic authority of the state'. This suggested solution for the end of political turmoil in the country relied on 
civil-military cooperation to implement repressive measures to fight against communism. ${ }^{38}$ However, the historical perspectives shared between the Turkish conservative political forces and the army ${ }^{39}$ precluded the TPP from challenging the post-1980 order too loudly or convincingly.

To overcome the limiting effect of this harmoniousness on the ability of the party to capitalize on civilianization issues, the third leader of the party, Cindoruk, directed his critique at the left for being responsible for the enduring political power of the military: 'Turkey has a problem called militarism, grounded largely in the left, being the source of anarchy and terror . . . this must be the problem of the left. The first and the most important phase we must go through is civilianization ... the left must also prioritize this goal and share the responsibility of reaching it. ${ }^{, 40}$ The assistant chair of the MP's parliamentary group, Haydar Özalp, summed up in 1986 the true source for the problem of ineffectiveness in the TPP's anti-militarist discourse: 'No rightwing political party can reject the essence of the 1982 Constitution. I don't think the TPP is doing that either. All they are doing is objecting to the bans against Demirel.' ${ }^{41}$

Another key factor which precluded the popularization of the TPP's discourse on civilianization was the phenomenal prestige of the military after the coup. The 1982 Constitution, which was a creation of the military government, received 91.9 per cent of the total votes cast in a referendum. Combined with the enormous popularity of the head of the coup, General Kenan Evren who was elected president in the same referendum, civilianization did not seem to be capable of being translated into political dividends, even in the eyes of its core supporters.

The last, but most important, reason why Demirel's appeal for democratization and civilianization did not make inroads into the political society was the continuing legacy of the utilitarian and unprincipled political calculus the DPJP line had with regard to the army. By what can be called a 'double discourse' strategy, ${ }^{42}$ the DP-JP-TPP have followed a conciliatory policy towards the military aimed at placating it. On the other hand, by giving prominence to the concept of 'national will' they have made feeble efforts to relegate the military to a politically subordinate position in the system. To the extent that this strategy is based on a pragmatic acknowledgment of the status quo, it represents the unwillingness of civilian political forces, especially the conservatives, to arouse the antagonism of the military.

As a seasoned leader who has faced two military coups and a seven-year political ban, Süleyman Demirel provides the best example of highly skilled management of both political equilibrium and the status quo. There are prolific examples of Demirel's politics of double discourse balancing in the post-1980 period. While in opposition, in May 1990, he said that 'the position of the general chief of staff should be under the minister of defense: Is Turkey a 
military democracy? ... This is a matter for the Constitution ... If you want civil society and a civil administration, you will have to conform to the rules in the west ... We are trying to do that, a reorganization is a must. ${ }^{93}$ Two years later, when he was the prime minister, he permitted the bill placing the general chief of staff under the minister of defense to be defeated with the votes of his party's members in the Parliamentary Defence Commission, on 14 May 1992. The same bill was defeated eight months later in the same commission by the same members of the ruling party. ${ }^{44}$

With Demirel's accession to leadership at the extraordinary general congress of 14 September 1987, two critical notions were added to the above democratization agenda as part of an identity-building process. The first was the incorporation of the principle of 'human rights' as the central ingredient in the discourse on democracy. Since concern for human rights had become an international issue, Demirel became the central protagonist publicizing the platform called the Paris Charter ${ }^{45}$ and linking it with human rights. The integration of universal rights and values into the democratic platform of the party found its expression in three documents. These were: the 1991 Election Manifesto; the Coalition Protocol signed with the SDPP on 19 November 1991; and the ensuing coalition government's programme. The second instrument, also included in the above-mentioned documents, strategically introduced into the democratization agenda the promise of revising, abolishing or improving domestic laws on political participation. Demirel's campaign to popularize and deepen the TPP's 'changed' perspective on democracy was justified as an instance of 'external push' in an era of internationalization: 'Turkey must accept universal values. Whatever the charter for the Conference on Security and Cooperation in Europe entails, Turkey must adjust its legal and constitutional order to it. ${ }^{36}$

Süleyman Demirel's discovery of universalized human rights through the Paris Charter as an electoral project was a direct response to the economistic and increasingly conservative discourse of the MP, especially after the election of its leader, Turgut Özal, as president in 1989. One major problem, however, emerged. How could the new identity markers of the party be spread to the political society without the political mediation of civil society organizations which had, in the past, bore the brunt of the JP governments' antipathy? The DP-JP line had traditionally disdained civil society and had kept its distance from both the lower and the intellectual social sectors. ${ }^{47}$ The cruel paradox of the party, having to seek a presence within the civil society whose politicization it had in the past opposed, coincided with the paradox of the post-1980 order itself. In engineering the exclusion of important sectors of civil society from democratic participation, the military and its civilian allies went so far in their repressive manipulations that the scarce commodity of 'democracy' gained unprecedented prestige. As a result, the civil society 
organizations underwent an awakening and a left-wing liberal movement, called 'civil societalism', emerged.

Even before Demirel's conversion to a human rights-oriented discourse, the TPP's strategists tried to enlist the support of civil societalists by the message that 'Demirel changed'.$^{48}$ It is true that during the days of Demirel's political prohibition the strategic compromise with the civil society was designed to channel its signs of revival towards the promotion of Demirel's cause, the lifting of the ban. The results of the 1991 general election provide ample evidence of the party's success in penetrating into civil society's broader sectors by a democratic and popularized discourse, without having to change its statist position. ${ }^{49}$

The TPP's first experience in political power was heading the coalition government it formed with the SDPP on 21 November $1991 .^{50}$ This government lasted until Demirel's move to the presidency and Çiller's election as party leader in 1993. It is not an exaggeration to say that this period under Demirel's premiership was not marked by any important policy shifts with regard to strategic implementation to consolidate its new identity based on welfarism, civilianization and human rights. The most important platform where the last two aspects could have been advanced was the Kurdish question. But here too, Demirel's reliance on a military solution became the major reason for the impasse on both dimensions.

In the extraordinary congress on 13 June 1993, Tansu Çiller's succession of the historic Süleyman Demirel ${ }^{51}$ marked a critical turning point for the future course of the TPP and the configuration of the Turkish Right. The 'female option' was chosen by the delegates as a means of inspiring confidence in those sectors of the society that had historical misgivings about the true 'liberal' nature of the TPP: the youth and women as well as those more educated and prosperous. At the time, Çiller was a wealthy economics professor and the minister of state for the economy. She seemed a perfect candidate, capable of forming intimate links with these strata through her personal identification with them.

Her election also reflected the historical/structural fault-line of the party, epitomized by the unchanging leadership of Demirel. The party tradition was so strongly conditioned by the tutelage of one powerful leader that when it came to the succession struggle none of the candidates could muster the necessary political resources, skill and support to compete effectively for the leadership. Under such conditions, Professor Çiller's election bore the imprint of Turkey's entry into a new age of politics: the growing power of the mass media as an augmenting force for political parties. By her telegenic 'charisma' she outshone her rivals ${ }^{52}$ in terms of 'visibility' in a party and culture where women in politics was a rarity.

There are four coordinates that distinguish Tansu Çiller's discourse on the 
party's identity from those of Demirel: the priorities she assigned to conservative-populism as an ideology and praxis friendly to state power; economism in terms of delinking market economy from political liberalism; managerialism as the key dimension of government performance; and sympathy for the military. All of these persuasions present a stark contrast to the earlier discourse of Demirel, who organized his convictions around welfarism, civilianization and democratization with an emphasis on human rights.

It is true to say that the political position of Çiller's discourse shifted from the centre to the right as she focused on themes of Turkish nationalism and those of a cultural-religious dimension. This was a nationalist-populist rhetoric centred on xenophobic elements of 'patriotism', 'flag', 'blood' and 'sacrifice' blended with religious items like 'ezan' (call to prayer), 'Allah' and 'being a Muslim' ${ }^{53}$ It is important to note that there is nothing new in Çiller's synthesis of conservative elements of Turkish nationalism and Islam. The original institutional source of this synthesis was the state-friendly group of conservative intellectuals, called the Hearth of Intellectuals. ${ }^{54}$ They had started disseminating their views in the 1970s and had gained stature among the state elite in the 1980s. Their main objective was to maintain the unity of the state and the status quo against communism. With communism removed from the world agenda, what would be the main purpose of Çiller's articulation of the same elements in the same old way? Additionally, since the political logic behind Çiller's succession to power was the concern felt by the party delegates over the failure of the party to achieve its self-declared objectives on equity and democracy, why would the post-Demirel leadership deviate from this course? Two clusters of elements must be considered relevant in the reversal of the earlier trend, one global and the other internal.

In the 1990s most of the new democracies of the non-western world, who had been experimenting with market economies since the late 1970s, entered into a political crisis which altered the tone and substance of their neoliberalism. A state of social despair resulted from their deep feeling of frustration with traditional representative democracy and state institutions. This was accompanied by an erosion of the membership support of the political parties and their governments. The vacuum created by this defection put a distance between the state and a fragmented society and was filled by "politics of antipolitics' and strong personalistic leaders appealing to the people directly. ${ }^{55}$ Tansu Çiller's premiership must also be considered against a backdrop of weak political parties and personalized politics globally.

Among the internal dynamics which are critical for appraising Çiller's nationalist-populist discourse is the concern for containing the dynamics unleashed by the process of liberalization within the limits of the official policy. In other words, Turkey of the 1990s has been marked not only by social disparities and uprootings caused by economic liberalism, but also by 
ethnic and religious divisions brought about by relative freedom afforded to channels of political organization and expression. By resolving the historic tension within the party between liberal and conservative elements, unambiguously in favour of the conservatives, Tansu Çiller aimed to provide certainty and security to the social base of the Turkish Right so as to enhance stability and the legitimacy of her rule. Moreover, nationalist-populist rhetoric was employed as a social control device to mobilize the masses into channels providing support for austerity policies: 'In the past our ancestors shed their blood, now we expect the same patriotism from our citizens in a different way ... This is a societal war ... Patriotism is not just shown on the battlefield ... We have to do the same in the economy. ${ }^{56}$

Çiller's conservative populism was strengthened by the war being waged against the Kurdish guerrilla insurgents of the PKK (Kurdistan Workers' Party). Involving 300,000 security forces and 20 per cent of the national budget, the Kurdish problem represents one of the basic parameters playing a conservatizing effect over the strategy and discourse of the Turkish Right. In this context, nationalism is used by all of the forces on the right as a unifying force against the disintegrative tendency of Kurdish nationalism, employing nationalist symbols, slogans and themes in the process. The most radical nationalist force on the Turkish Right is the Nationalist Action Party (NAP) and its leader, Alpaslan Turkeş. The NAP has become the behind-the-scenes coalition partner of the TPP, after having undergone an image-cleaning operation in the press $^{57}$ for political violence they were involved in against the left in the 1970 s..$^{58}$

The political expression of the Islamic movement, the Welfare Party (WP), and the MP must also be considered in the analysis of Tansu Çiller's new course. The WP can be perceiyed as fruit from the performance failure of the Turkish Right, which had been in power most of the time during the multiparty period. ${ }^{59}$ With a broadening power base, which includes the protest vote of those having suffered under competitive market conditions since 1980 , the WP is the most serious competitor of all the parties on the right. ${ }^{60}$ The conservative-populist appeal of the TPP since Tansu Çiller took over is an attempt to recapture those sectors lost to the WP, the new epicentre of Turkish politics.

Finally, it can be claimed that the ideological and structural crisis of the MP is partly responsible for Çiller's abandonment of the precepts of political liberalism. Coming from a tradition which relied on defining itself in relation to the 'negative other', the need for this tactic diminished as the MP lost much of its earlier vibrancy. In other words, once it became clear that the costs of not implementing the platform of human rights, participation and democracy would be nil in terms of loss of support for the MP, the 'democratization package', ${ }^{61}$ as it was popularly called since the formative days of the party, 
became insignificant. The TPP, despite objections from its social democratic coalition partner, has actually worked to postpone this package.

In the face of a socio-economic crisis at home, Çiller's change of discourse basically aimed at reducing the uncertainties arising from ideological diversity and compromise between liberal and conservative elements in the party. This can be taken as a tacit acknowledgement that her power base in the party is vulnerable. Being catapulted into power in a party which was identified with the rather undemocratic rule of one man, and being surrounded with diehard followers of that one man, it is quite natural for her to have felt insecure and so employ the good old 'traditional' modes of leadership to which the party was accustomed. By adhering to a personalistic decision-making style and by continuing to buy support with clientelist rewards of office, she effectively removed Demirel's supporters from party posts. In time, by also using the tactical advantage of being a woman leader, she has managed to neutralize any serious opposition to her rule. All in all, in her ideology and praxis, Çiller has largely subscribed to the logic of 'old' rather than 'neo' liberalism. However, to the extent that she is the product of a background characterized by the impasse of liberalization, she is a typical politician of the 'politics of antipolitics'.

There is no doubt that Çiller's ardent commitment to free-market orthodoxy, ${ }^{62}$ and to an anti-populist and anti-welfare platform, bears more resemblance to the stance of the founder of the main opposition party (MP), Turgut Özal, than it does to her own party's former leader, Süleyman Demirel. By her rhetorical return to an Özalist priority of establishing a competitive market economy through the instruments of privatization, liberalization and stabilization, she ended the historical eclecticism of the TPP's dominant ideological discourse between the social state and free-market rationale.

Çiller's conceptualization of the state depended on its demystification. By referring to 'the state's money being the people's money', ${ }^{63}$ Çiller seemed to launch an assault against the inefficiency of the populist state. Creation of an overriding antagonism between the state and the people, however, had no reference to the institutional and constitutional limits of the state protecting individual rights while advancing the principle of majority rule. Reinforced by her nationalist discourse, the people-state dichotomy tried to overcome the existence of a multi-dimensional and complex political space while preventing ethnicity from being the dominant mode of political antagonism: 'There are not only unions ... the unemployed or the people of Kurdish origin. Today there are miners, women ... When all these are organized, the polyphony of these organizations will be a necessary dimension of democracy. The state will be only one of those actors. ${ }^{64}$

However, Çiller's verbal downgrading of the over-determining role of the state has been undermined by her populist policies of clientelism and state- 
administered patronage, aimed at winning votes, and by the continuing structure of a state-directed economy. She has defended herself in part by blaming the delaying tactics of her coalition partner in passing the legal framework for privatization, the coalition government's main political platform. But Turkey's experiment with liberalization à la Çiller seems to be notable for what it is missing: there is an absence of a 'civil philosophy' for a limited state; no western-type liberal democracy; and a lack of fundamental concern for the rule of law, democratic legitimacy, human freedom with dignity and civil associations. ${ }^{65}$ Far more important than any of these has been the priority given to efficiency in a 'managerial' state. It is important to note that this particular concept, which indexes government popularity to performance, is not based on a philosophical concern to limit the power of the state. ${ }^{66}$ Nor is it true to say that the TPP, under Çiller's leadership, has confronted many of the pressing issues related to social justice, economic development and political reform so as to be rightly classified as 'managerial'.

It would be correct to claim that the rhetorical commitment to economic liberalism under Çiller was necessitated as much by the prevalence of freemarket ideology, both at home and globally, as it was by the pragmatic constraints of the state's financial crisis. It also seems that the pro-democracy tenet that formed the backbone of the TPP's political identity in the pre-Çiller period figures less prominently in the party's discourse today. The chief reason for this reversal is the pragmatic acknowledgement by the leadership of the status quo. In this sense, the full consensus between the present government and the military represents yet another instance of the reluctance of the party leadership to arouse the antagonism of the military by upsetting the status quo. When in August 1993 and 1994 the question of the appointment of the general chief of staff arose, Tansu Çiller refrained from taking any initiative and instead endorsed the wishes of the military hierarchy on the issue. This position was taken in order to consolidate her political authority through an alignment with the military bureaucracy. The double-discourse of the TPP on civilian-military relations was, therefore, reduced to the single course of abandoning any pretence to reassert civilian supremacy in the Turkish political system.

In many countries of the non-western world, political parties and political systems seem to be in a crisis state. The collapse of the iron curtain, the exhaustion of state-led development models and the burdens imposed by economic stabilization programmes have apparently overwhelmed the political process. In Turkey, too, the formal institutional framework containing the political parties can neither accomodate the past fourteen years of social change nor articulate the new model politically. There is, therefore, a growing public exasperation over the inefficiency and ineffectiveness of the state and the political parties. 
What have been the reasons underlying the TPP's identity crisis? First of all, its ambiguous political outlook and style have been disguised as pragmatism. The party has also traditionally been characterized by an aversion to democratic legitimation of power, including a neglect for the rule of law and for genuine societal pluralism, in a western liberal sense. This position has resulted in limiting the party's capacity for action, which is why the presentday TPP cannot expand constitutional liberties and initiate market-oriented reforms, even at a time when the public is willing to undergo sacrifices as a sign of support. More seriously, the question of ideological fuzziness has contributed to the endemic uncertainty and instability of the political system. This, in turn, has further prevented the party from consistently taking liberal positions, hence the vicious circle.

On the positive side, the formation and evolution of the TPP and its predecessors represent historical milestones in the institutionalization of democratic participation in Turkey. Against a background of dramatic destabilization caused by rapid social and economic changes and military interventions, this political tradition has provided relative stability, prosperity and legitimacy to the regime by integrating the masses into the system through populism.

\section{NOTES}

1. On the defining characteristics of neo-liberalism see Francis Fukuyama, 'The End of History', The National Interest, No.16 (Summer 1989), pp.3-18; 'Liberal Democracy as a Global Phenomenon', Political Science and Politics, Vol.24, No.4 (1991), pp.659-64; Bob Jessop et al., 'Farewell to Thatcherism - Neo Liberalism and New Times', New Left Review, No.179 (1990), pp.81-102; for its implications in Latin America see Lawrence Whitehead, "The Alternatives to "Liberal Democracy": a Latin American Perspective', Political Studies, Vol.XL, Special Issue, David Held (ed.), pp.146-59.

2. The term the Turkish Right indicates one polar space on the left-right ideological spectrum consisting of three visible positions: the religious right, the radical nationalist right and the centre-right. Since 'conservative' and 'liberal' ideologies are found in forms of impure amalgamations in the discourse of all these three positions, there are difficulties in defining the Turkish Right in terms of ideologies. The centre-right parties, however, have held power in most of the multi-party period since 1946.

3. The term is borrowed from an analysis on Latin America. See Atilio A. Boron, 'Becoming Democrats? Some Sceptical Considerations on the Right in Latin America', in Douglas A. Chalmers et al. (eds.), The Right and Democracy in Latin America (New York, 1992), p.80.

4. On the importance of continuing features of structuration of society. by the military in the post-military period in Latin America see Francis Hagopian, 'Democracy by Undemocratic Means? Elites, Political Pacts, and Regime Transition in Brazil', Comparative Political Studies, Vol.23, No.2 (1970), pp.147-70.

5. Ilter Turan, 'Political Parties and the Party System in Post-1983 Turkey', in Metin Heper and Ahmet Evin (eds.), State, Democracy and the Military: Turkey in the 1980's (Berlin and New York, 1988), pp.63-80.

6. See S.M. Lipset, 'Neoconservatism - Myth and Reality', Society, Vol.25, No.5 (1988), pp.29-37; on Latin America see Boron, 'Becoming Democrats? Some Sceptical Considerations on the Right in Latin America'. 
7. Within a span of 78 days from the day of its foundation, the TPP faced a relentless onslaught of vetoes by the military rulers. By vetoes, it lost 57 of its 88 founding members and one leader and, worse still, although it was able to pass the required threshold of 30 founders by 1 by 22 July 1983, through the deliberate delaying of the military to endorse the list it was precluded from entering into the 1983 elections.

8. In the first elections it could contest (24 March 1984 local elections) the catastrophic state of its votes (14 per cent as opposed to the MP's 42 per cent) and the lawsuit opened by the Public Prosecutor in the Constitutional Court to close the TPP further demoralized the party. The fact that the constitutional article banning the ex-leaders of the pre-1980 political parties from political activity was lifted by a plebiscite in 1987 by only a narrow margin of 0.6 points, delivered another blow to the self-confidence of the leadership and cadres. Until it emerged as the second electoral force after the Social Democrat People's Party (SDPP) in the 26 March 1989 local elections, pushing the MP to a third position, the party's downward trend continued.

9. Süleyman Demirel, DYP 2. Büyük Kongresi Açış Konuşması [Süleyman Demirel, Opening Speech at the Serond TPP Congress] (Ankara, 1988), p.29.

10. Within six months of its foundation, it became the leading party by scoring 45.1 per cent of the total votes and 211 seats in the 450 member parliament in the 1983 general elections. Its uncontestable leadership of the Turkish Right continued in the 1987 general elections, despite a loss of 8.8 per cent in its share of votes compared with the previous election. In the 1989 local elections, the MP was reduced to the third position, losing support to the TPP which became the second largest political party. The general elections of 1991, by making the TPP the leader of the centre-right, confirmed the upward trend for this party.

11. Üstün Ergüder, 'The Motherland Party, 1983-1989', Metin Heper and Jacob Landau (eds.), Political Parties and Democracy in Turkey (London, 1991), pp.152-169.

12. Üstün Ergüder, 'Liberalism and the Motherland Party', Ilber Ortaylı, (moderator), Liberal Elements in the Programmes of Turkish Political Parties - Economic Policy and Industrialization (Ankara, 1992), pp.35-49.

13. Two of the parties on the right, the pro-Islamic Welfare Party (WP) and the ultra-nationalist Nationalist Work Party (NWP), though unable to pass the national threshold of 10 per cent in both the 1987 and 1989 elections, scored some percentage increases in their votes (WP 2.7 per cent, NWP 1.2 per cent). The two parties, by entering into an electoral alliance, were able to receive 16.7 per cent of the votes in the 1991 elections.

14. Çağlar Keyder, Ulusal Kalkınmacılığın Iflası [The Bankruptcy of National Development] (Istanbul, 1993), pp.32-49.

15. Nilüfer Göle, '1980 Sonrası Politik Kültür' [Political Culture after 1980], Türkiye Günlüğü, No.21 (Kış), p.52.

16. Nokta (Istanbul Weekly), 29 May 1988, p.18.

17. Ibid.

18. The three most important names brought to top positions in the party were Hüsamettin Cindoruk, Ersin Faralyalı (a businessman) and Tansu Çiller.

19. W.B. Sherwood, 'The Rise of the Justice Party in Turkey', World Politics, No.20 (1968), p.55.

20. Quoted in Feroz Ahmad, The Turkish Experiment in Democracy (London, 1977), p.23.

21. Reşat Kasaba, 'Populism and Democracy in Turkey', in Ellis Goldberg et al. (eds.), Rules and Rights in the Middle East - Democracy, Law and Society (Seattle and London, 1993), p.50.

22. On the Kemalist state's lack of mobilizing power of the traditionally oriented masses see Feroz Ahmad, 'the Political Economy of Kemalism', in Ali Kazancigil and Ergün Özbudun (eds.), Atatürk, The Founder of a Modern State (London, 1981), pp.160-61; and Ergün Özbudun, 'The Nature of Kemalist Political Regime', in ibid., pp.79-102.

23. Attilio Boron, 'Becoming Democrats? Some Skeptical Considerations on the Right in Latin America', p.89.

24. Kasaba, 'Populism and Democracy in Turkey', p.53.

25. Süleyman Demirel, 'Artık Demokrasiler Tezsizdir' [Democracies Now Have No AntiThesis], in Hıdır Göktaş and Ruşen Çakır (eds.), Vatan, Millet, Pragmatizm - Türk Sağında Ideoloji ve Politika [Fatherland, Nation, Pragmatism - Ideology and Politics on the Turkish 
Right] (Istanbul, 1991), p.21.

26. 'Cindoruk'la Sol, Sağ ve Militarizm Sorunu' [The Problem of the Left, Right and Militarism with Cindoruk], Yeni Gündem (Istanbul Weekly), 23 (1-15 Haziran, 1985), p.10.

27. Ibid.

28. 21 Ekim Sabahı Yeni Bir Türkiye - Seçim Bildirgesi 1991 [A New Turkey on the Morning of October 21 - Election Manifesto] (No bibliographical info.).

29. Doğru Yol Partisi Genel Başkanı Süleyman Demirel'in Basın Toplantısı [The Press Conference by the True Path Party Leader, Süleyman Demirel] (1 Ekim 1991) (no bibliographical info.).

30. DYP Genel Başkanı ve Başbakan Tansu Çiller'in Konuşmaları - 19 Haziran - 5 Kasım 1993 [The Speeches of the Leader of the TPP and the Prime Minister, Tansu Çiller], pp.98, 121.

31. For the origins of the concept of national will in the formative years of the Republic when it was used to deny class conflict see Ilkay Sunar, State and Society in Politics of Turkey's Development (Ankara, 1974), pp.62-4.

32. Noel O' Sullivan, 'Political Integration, the Limited State, and the Philosophy of PostModernism', Political Studies - Special Issue, the End of 'Isms'?, Vol.XLI (1993), pp.21-42; David Beetham, 'Liberal Democracy and the Limits of Democratization', Political Studies Special Issue, Prospects for Democracy, David Held (ed.), Vol.XL (1992).

33. 'This government has aimed at enforcing political power it has taken over from the 12 September 1980 administration . . . without . . . regard for, and despite of, the national will.' Doğru Yol Partisi Bir Yaşında [The TPP is One Year Old] (Ankara: DYP Yayınları, no date), p.14.

34. For the constitutional powers accorded to the military by the 1983 Constitution see George Harris, 'The Role of the Military in Turkey in the 1980's: Guardians or Decision-Makers?', in Heper and Evin, State, Democracy and the Military in Turkey in the 1980's, pp.177-200.

35. Süleyman Demirel, Türk Demokrasisi Meydan Okuyor [Turkish Democracy is On the Challege] (1989 Mali Yılı Bütçesi Vesilesiyle TBMM'de 9 ve 23 Aralık 1988'de Yaptığı Konuşmalar) (Ankara: DYP Basın ve Propoganda Başkanlığı, no date of publication), p.133.

36. Ibid.

37. Despite the rather inflated image of the leader of the MP, Turgut Özal, as a challenger of the military's political power, and his seeming success in imposing the choice of his civilian government on the appointment of the general chief of staff in 1987, he could not have acted in this manner if he had not procured the support of the then-president, the leader of the coup, ex-general Kenan Evren. Nor did he make any changes in the legal framework which facilitates the political presence of the army in politics.

38. Ümit Cizre Sakallığlu, AP - Ordu Ilişkileri - Bir Ikilemin Anatomisi [The Relations between the Justice Party and the Military: The Anatomy of a Dilemma] (Ankara, 1993), pp. 174-94.

39. It must be noted that the historical pattern of this political cooperation between the two sides has developed against reactionary Islam, ethnic secessionism and the communist challenge to the state.

40. 'Cindoruk'la Sol, Sağ ve Militarizm Sorunu', p.23.

41. 'Çankaya Ne Düşünüyor?' [What does Çankaya - the site of the Presidential ResidenceThink?], Nokta (19 Ocak 1986), p.13.

42. Sakallığlu, AP - Ordu Ilişskileri.

43. Süleyman Demirel, ' 12 Eylül Vaadleri Tutulmadı' [The 12 September Promises Were Not Kept], Milliyet (Istanbul daily), 28 May 1990.

44. See Hürriyet (Istanbul daily), 15 January 1993.

45. 'Paris Charter for a New Europe' was signed on 21 November 1990 among the members of the Conference on Security and Cooperation in Europe (CSCE), basically on the issue of human rights.

46. Doğru Yol Partisi Genel Başkanı Süleyman Demirel'in Basın Toplantısı (1 Ekim 1991), p.14.

47. Sherwood, 'The Rise of the Justice Party in Turkey', p.64.

48. Mehmet Ali Birand, 'Demirel Çok Kişiyi Utandıracak' [Demirel will Embarrass Many People], Milliyet, 6 September 1991.

49. Perhaps the best standard to measure the success of the rhetoric 'Demirel Changed' in gaining 
hold of the urbanites is to compare the votes the party scored in the 1987 and 1991 general elections in the cities. While in 1987 it received more than 40 per cent of all the votes in 1 city, the number rose to 2 cities in 1991; the number of cities it received between $30-40$ per cent of the votes increased from 3 in 1987 to 26 cities in 1991; the number of cities where it received between 20-30 per cent was 30 in 1987, it rose to 31 in 1991; the number of cities it collected less than 20 per cent of the votes fell from 26 to 14. Sources: the Results of the 1987 and 1991 General Elections as published in the Official Gazette No.19659, 9 December 1987 and No.21038, 1 November 1991.

50. In the 1991 general elections, while the MP suffered a 12 point radical defeat and scored 24 per cent, the TPP managed to raise its votes from 19.1 per cent in 1987 to 27 per cent. The SDPP, on the other hand, received 20.75 per cent as compared with 24.8 per cent in 1987.

51. Süleyman Demirel was elected as president on 16 May 1993 upon the unexpected death of Turgut Özal, his main rival and the former leader of the MP, on 17 April 1993.

52. One contender was Köksal Toptan, a leader of a faction garnering support from a nationalistconservative base. Another was Bedrettin Dalan, whose accomplishments as the ex-mayor of Istanbul had been tarnished by his switch of loyalty from his original party, the MP, to the TPP. A third rival was Ismet Sezgin, a senior member of the party who was thought to have the undeclared support of Demirel.

53. DYP Genel Başkanı ve Başbakan Tansu Çiller'in Konuşmaları - 19 Haziran - 5 Kasım 1993 (Ankara: Başbakanlık Basın Merkezi), pp.13, 62, 95; Ertuğrul Özkök, 'Çiller: Türkiye Milliyetçiliği Doğdu' [Turkey's Nationalism is Born], Hürriyet, 31 October 1994.

54. See Ilhan Tekeli, 'Türk Islam Sentezi Üzerine' [On Turkish-Islamic Synthesis], Bilim ve Sanat, 77 (Mayis 1987), pp.5-8; also, Gencay Șaylan, Islamiyet ve Siyaset [Islam and Politics] (Ankara: V. Yayınlan, 1987), pp.68-9.

55. For a vivid portrayal of new patterns of politics in Latin America and Eastern Europe see Francisco C. Weffort, 'New Democracies, Which Democracies?', Working Paper No.198 (The Woodrow Wilson Center:Washington, 1992).

56. Başbakan Tansu Çiller'in TBMM Grup Konuşmaları - 22 Haziran - 2 Kasım 1993 [Prime Minister Tansu Çiller's Speeches in Her Parliamentary Group] (Başbakanlık Basın Merkezi), p.53.

57. Ertuğrul Özkök, 'Türkeş’i Öveceğime Hiç Inanmazdım' [I Never Believed I Would Praise Türkeş], Hürriyet, 15 May 1993.

58. Ümit Cizre Sakallığlu, 'The Ideology and Politics of the Nationalist Action Party of Turkey', C.E.M.O.T.I. (Cahiers D' Études Sur La Méditerranée Orientale et Le Monde Turco - Iranien], No.13 (1992), pp.141-64.

59. For a representative sample of the argument that it is not the strength of religious orthhodoxy but the weakness of centre-right parties that lies behind the WP's electoral success see Ruşen Çakır, 'Refah Çalıştı Haketti Kazandı' [The WP Labored and Earned what they Deserved], Sabah (Istanbul Daily), 12 April 1994; A. Yaşar Sarıbay, 'Refah Partisinin Ardındaki Sosyo-Politik Dinamikler' [The Socio-Political Dynamics Behind the WP], Türkiye Günlüğü, No.27 (March- April 1994).

60. The WP has scored the largest increase of votes ( 9.2 per cent) among all the Turkish political parties between the 1989 and 1994 local elections. The same comparison cannot be made regarding the last two general elections of 1987 and 1991 since the WP made an electoral alliance with two other parties, the NAP and a smaller party, on the radical right before the last one.

61. The package comprised a promise of amending 22 articles of the Constitution and of nine changes in some laws related to the Constitution with a view to widening the channels of political participation. It was brought before the parliament one year after Çiller took over. Deliberations on it entered a deadlock on article 8 of the law on Struggle Against Terrorism, which with the proposed amendment would include the crimes against secularism. The hardliners within the TPP, together with arch-conservative politicians entrenched in the other right-wing parties, formed a coalition objecting to this new inclusion and have since blocked this process. See Demokratikleşme ve Yeniden Yapılanma Uygulama Planı [The Plan on Restructuring and Implementing Democratization] (Ankara, 18 May 1994).

62. Since she started her political career, she has opened two austerity packages. One on 18 
January 1992 called 'An Equilibrium, Production and Improvement Program for the Economy', which was called by some economy columnists as 'revolutionary' (see Osman Ulagay, 'Çiller in Devrimci Programı' [Çiller's Revolutionary Program], Cumhuriyet (Istanbul daily), 21 January 1992). The second such package was on 5 April 1994, called 'The 5 April Measures', opened not as planned but in an economic crisis caused by political miscalculations. On the dismal failure of the latter which soon became obvious see ' 9 Ay Hovardalık, 3 Ay Istikrar' [Extravagence for 9 Months, Austerity for 3 Months], Milliyet, 30 June 1994; ' 5 Nisan Iflas Etti' [5 April Has Gone Bankrupt], Hürriyet, 5 November 1994; 'Ekonomi Yüzde 10.6 Küçüldü' [The Economy Shrank by 10.6 Percent], Hürriyet, 1 September 1994.

63. See Başbakan Tansu Çiller'in TBMM DYP Grup Konuşmaları - 22 Haziran - 2 Kasım 1993. pp. $99,101,102,110$.

64. DYP Genel Başkanı ve Başbakan Tansu Çiller'in Konuşmaları - 19 Haziran - 5 Kasım 1993 , p.77.

65. Noel O'Sullivan, 'The New Right: The Quest for a Civil Philosophy in Europe and America', in Roger Eatwell and Noel O'Sullivan (eds.), The Nature of the Right (London, 1989), pp.168-71.

66. Ibid., p. 169. 